Brit. Heart F., 1967, 29, 783.

\title{
Propranolol in Management of Muscular Subaortic Stenosis
}

\author{
GRAEME SLOMAN \\ From the Cardiac Department, Royal Melbourne Hospital, Melbourne, Australia
}

Muscular subaortic stenosis (Wigle, Heimbecker, and Gunton, 1962) is one of the names used to describe functional ventricular obstruction which simulates aortic valve stenosis. Other workers (Brock, 1957, 1959; Teare, 1958; Morrow and Braunwald, 1959; Brent et al., 1960; Brockenbrough, Braunwald, and Morrow, 1961; Goodwin et al., 1960) have also emphasized the functional nature of the myocardial obstruction. Criley et al. (1965) developed a new concept of the condition, illustrating seven patients in whom there was a pressure gradient without obstruction.

Braunwald and Ebert (1962) and others have shown that increased beta-adrenergic stimulation increased the apparent obstruction to flow, from both the right and the left ventricle in muscular subaortic stenosis. It has been shown that digitalis has a similar action (Braunwald, Brockenbrough, and Frye, 1962).

Cohen et al. (1964) studied the acute effect of beta-adrenergic blockade in patients with muscular subaortic stenosis using pronethalol during cardiac catheterization, and later Cherian et al.(1966) showed that propranolol would prevent the increase in dynamic obstruction which occurred with exercise or isoprenaline infusion. It was noted that propranolol had very little or no effect on the hæmodynamics at rest.

The importance of the adrenergic nervous system in this condition was reinforced by the findings of Everson Pearse (1964), who examined operative specimens of ventricular septal myocardium from two patients and showed an increased amount of noradrenaline in the hypertrophied muscle. This observation of increased noradrenaline store has been confirmed in one patient submitted to ventriculomyotomy at the Royal Melbourne Hospital (G. Burnstock, personal communication, 1966).

Received December 19, 1966.
All evidence points to the involvement of the betaadrenergic receptors in the myocardium as being involved in muscular subaortic stenosis. The value of prolonged beta-adrenergic blockade was studied in a group of patients with the clinical and hæmodynamic features of muscular subaortic stenosis. This paper presents our observation in five patients treated with the beta-adrenergic blocking drug, propranolol.

\section{SubJECTS AND MeThodS}

Five patients with clinical evidence of muscular subaortic stenosis were selected for study. There were two women and three men. Their ages ranged from 19 years to 53 years. The diagnosis was established in all by right and left heart catheterization with cine-angiocardiography (Table I). Left ventriculography was most useful in confirming the diagnosis. In all five patients selected, there was hypertrophy of the interventricular septum and papillary muscles. In all patients cine-angiocardiography demonstrated a variable degree of mitral regurgitation. It was noted that the left ventricular cavity emptied very rapidly and that pockets of the left ventricular cavity were devoid of contrast medium in late systole. This appearance conformed with the description of cavity evacuation (Criley et al., 1965).

The ventilatory capacity was assessed from a forced expiratory spirogram recorded with a low resistance spirometer; and the forced expiratory volume at one second $\left(F^{2} V_{1}\right)$ was read off with a scaled transparent protractor. The vital capacity was estimated in the conventional manner from an unhurried expiration. For both $\mathrm{FEV}_{1}$ and vital capacity the highest reading from several attempts was accepted and all gas volumes were expressed as volumes at body temperature, ambient pressure, and saturated with water vapour. An exercise test was used to assess the ventilatory response to exercise. The test was as described by Sloman and Gandevia (1964). The patients climbed up and down steps at a steady rate for 5 minutes, the work performed being controlled by adjusting the step height and the rate of 783 
TABLE I

CLINICAL PRESENTATION AND PRESSURE GRADIENTS

\begin{tabular}{|c|c|c|c|c|c|c|c|}
\hline \multirow{2}{*}{ Patient } & \multirow{2}{*}{ Sex and age } & \multirow{2}{*}{ Major symptoms } & \multicolumn{4}{|c|}{ Pressures (mm. $\mathbf{H g}$ ) } & \multirow{2}{*}{$\underset{\text { incidence }}{\text { Family }}$} \\
\hline & & & $\begin{array}{c}\text { Left } \\
\text { ventricle }\end{array}$ & Aorta & $\begin{array}{c}\text { Right } \\
\text { ventricle }\end{array}$ & $\begin{array}{l}\text { Pulmonary } \\
\text { artery }\end{array}$ & \\
\hline $\begin{array}{l}\text { B. H. } \\
\text { S. H. }\end{array}$ & $\begin{array}{ll}M & 29 \\
M & 27\end{array}$ & $\begin{array}{l}\text { Syncope, palpitations, dyspncea } \\
\text { Syncope, dizziness, dyspnœea, }\end{array}$ & $\begin{array}{l}105 / 5 \\
165 / 15\end{array}$ & $\begin{array}{r}105 / 50 \\
90 / 55\end{array}$ & $\begin{array}{l}50 / 0 \\
30 / 0\end{array}$ & $\begin{array}{l}18 / 5 \\
20 / 5\end{array}$ & + \\
\hline $\begin{array}{l}\text { J. W. C. } \\
\text { J. L. } \\
\text { B. T. }\end{array}$ & $\begin{array}{ll}M & 53 \\
F & 40 \\
F & 19\end{array}$ & $\begin{array}{l}\text { Syncope, dizziness, dyspnœea } \\
\text { Dizziness, fatigue, œdema } \\
\text { Syncope, angina }\end{array}$ & $\begin{array}{l}130 / 15 \\
225 / 15 \\
130 / 10\end{array}$ & $\begin{array}{r}120 / 80 \\
130 / 80 \\
90 / 60\end{array}$ & $\begin{array}{l}35 / 5 \\
90 / 10 \\
35 / 5\end{array}$ & $\begin{array}{l}30 / 8 \\
90 / 40 \\
30 / 15\end{array}$ & $\begin{array}{r}+ \\
0 \\
+\end{array}$ \\
\hline
\end{tabular}

level was varied according to the patient's exercise tolerance.

Ventilation was measured with a Wright ventilometer at rest, during exercise, and during recovery. The excess ventilation over and above the resting level during both exercise and recovery phases was calculated and then divided by the work done. This gives a figure in litres of ventilation per kilogram-metre per minute (1./kg.m./min.) which is independent of the work level employed. Multiplying by 300 indicates the excess ventilation in litres per minute required by the subject if exercised at $300 \mathrm{~kg} . \mathrm{m} . / \mathrm{min}$.

The physical working capacity (PWC) was also used as a measure of exercise capacity before and during treatment with beta-adrenergic blockade. It was determined by walking the patient on a motor-driven treadmill with the footpath inclined at a 5 degree angle (Pitt, Sloman, and Munro, 1964). The heart rate was constantly recorded by an electrocardiogram taken from chest electrodes. The amount of work was varied by adjusting the speed of the footpath which was accurately measured with a calibrated speedometer wheel in direct contact with the moving footpath. The cardiogram was monitored at rest and during all periods of exercise. The patient was exercised at 3 or 4 work levels with a three-minute rest period between each level. The $\mathrm{PWC}_{150}$ was taken as the speed of the treadmill when the heart rate was 150 beats a minute (Sjostrand, 1960; Hellerstein et al., 1963). If this heart rate could not be reached then the $\mathrm{PWC}_{150}$ was calculated by extrapolating the measurements of the heart rate at the lower work levels. In one patient an acute study was carried out to record the changes in heart rate after first giving an intravenous dose of propranolol alone, and then propranolol in conjunction with atropine (Fig. 1).

After confirmation of the diagnosis the patients were given propranolol $10 \mathrm{mg}$. three times a day and at night, and the dose was increased to a maximum of $40 \mathrm{mg}$. three times a day, in an attempt to obtain optimal improvement. Four patients remained on therapy for from 6 to 15 months. The fifth patient (J. L.) was taken off treatment after 3 months because of increasing short-

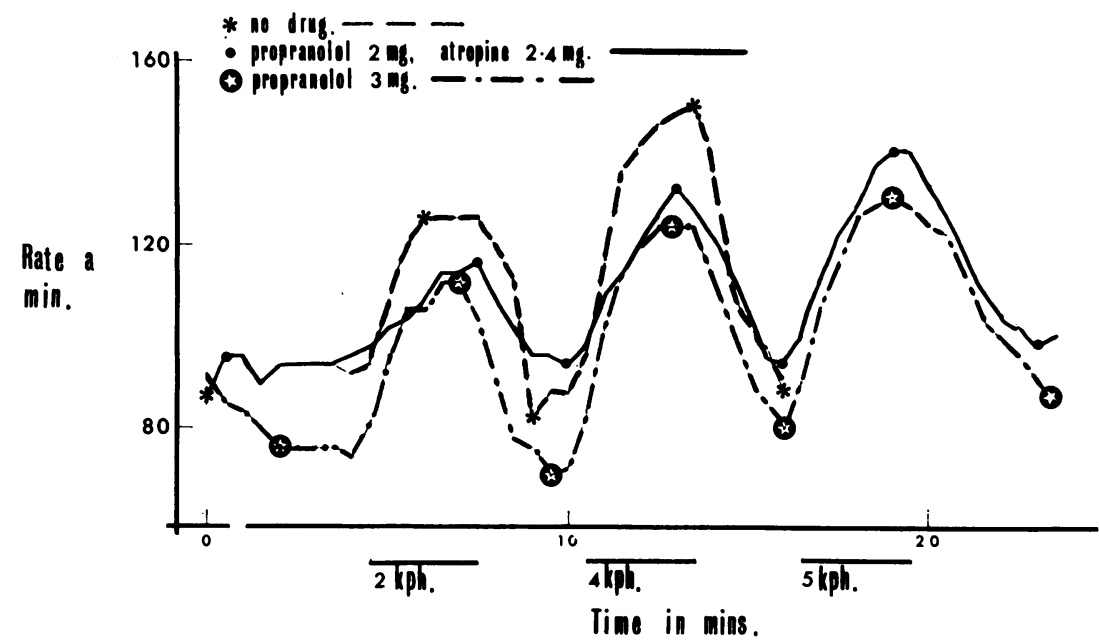

Fig. 1. - The acute response to intravenous propranolol as judged by the heart rate response during exercise. The test was repeated three times: (1) with no medication; (2) with $3 \mathrm{mg}$. propranolol administered intravenously; and (3) with an additional dose of $2 \mathrm{mg}$. propranolol intravenously together with $2.4 \mathrm{mg}$. atropine sulphate. The patient rested for 15 minutes between each test. 
ness of breath and progressive ankle œdema. Propantheline bromide was used in two patients in a dose of $15 \mathrm{mg}$. twice a day to counteract the unpleasant sideeffects of the unmasked vagal activity.

Patients were followed by regular clinical assessment, chest $x$-ray examination, and electrocardiography. The ventilatory responses to exercise and the physical working capacity tests were repeated frequently in an attempt to obtain objective assessment of the patients' progress.

\section{RESULTS}

Four patients reported initial improvement. Dizziness on exertion and syncopal attacks which had been present in all four were abolished. Anterior chest pain due to myocardial ischæmia was less frequent. The exercise tolerance as assessed by the patient was increased. In three patients, despite increasing doses of propranolol, the initial improvement was not maintained. No syncopal attacks occurred in these patients while on treatment; however, minor dizzy turns were noted and three patients experienced a recurrence of shortness of breath.

One patient (B. T.) reported dramatic improvement after starting therapy and this improvement was maintained for 9 months. There was complete freedom from syncope and dizzy turns. The anterior chest pain, which had been present on moderate activity before treatment, did not return. The patient commenced to swim and dance again. The fifth patient (J. L.) deteriorated on treatment. The shortness of breath was troublesome and fluid accumulated in the lower extremities. In this patient, who was in atrial fibrillation, propranolol caused slowing of the heart rate, both at rest and on exercise. Despite this dramatic effect, there was general deterioration while the patient continued on this treatment. Withdrawal of propranolol was associated with considerable improvement.
During treatment there was no consistent change in the resting blood pressure in any patient. The heart rate was slowed in all patients, with a mean casual heart rate before treatment of 94 a minute and after treatment of 70 a minute. Auscultatory findings were not altered during the period of treatment; however, the systolic murmur varied in intensity from examination to examination and was always accentuated by exercise and was best heard in full expiration.

Radiological examination did not show any significant change in cardiac size in four of the patients. However, in J. L. the heart size increased with associated pulmonary venous congestion. The serial electrocardiograms showed no alteration during the period of observation, except for the general heart rate slowing.

Ventilatory Capacity and Ventilatory Response to Exercise. There was no change in the ventilatory capacity during treatment with propranolol. The ventilatory response to exercise was increased in two patients and decreased in one patient (B. T.) (Table II). It was not possible to repeat the ventilatory response to exercise tests on J. L. while receiving treatment, because of the increase in shortness of breath and limitation in physical activity.

Physical Working Capacity Tests. A heart ratework ratio (PWC) was measured in all patients (Table III). One patient (J. L.) preferred to be tested on a bicycle ergometer while the remainder carried out their tests on a motor-driven treadmill with the footpath inclined at five degrees. While receiving propranolol all patients demonstrated a reduction in the resting heart rate, standing on the treadmill, before starting the exercise. The average reduction in heart rate was 28 beats a minute.

TABLE II

VENTILATORY RESPONSE TO EXERCISE BEFORE AND DURING TREATMENT WITH PROPRANOLOL

\begin{tabular}{|c|c|c|c|c|}
\hline \multirow[b]{2}{*}{ Patient } & \multirow{2}{*}{$\begin{array}{l}\text { Before or } \\
\text { during } \\
\text { treatment }\end{array}$} & \multicolumn{3}{|c|}{ Ventilatory response to exercise } \\
\hline & & $\begin{array}{c}\text { Resting } \\
\text { heart } \\
\text { rate/min. }\end{array}$ & $\begin{array}{c}\text { Maximum } \\
\text { heart } \\
\text { rate/min. }\end{array}$ & $\underset{\left(1 . / \min ^{300^{\star}}\right)}{\mathrm{SV}_{(1)}}$ \\
\hline $\begin{array}{l}\text { B. H. } \\
\text { S. H. } \\
\text { J. W. C. } \\
\text { J. L. } \\
\text { B. T. }\end{array}$ & $\begin{array}{l}\text { Before } \\
\text { During } \\
\text { Before } \\
\text { During } \\
\text { Before } \\
\text { During } \\
\text { Before } \\
\text { During } \\
\text { Before } \\
\text { During }\end{array}$ & $\begin{array}{l} \\
74 \\
84 \\
64 \\
84 \\
80 \\
82 \\
78 \\
68\end{array}$ & $\begin{array}{l}\overline{110} \\
138 \\
134 \\
108 \\
106 \\
140 \\
\overline{138} \\
120\end{array}$ & $\begin{array}{l}-\overline{38 \cdot 8} \\
34 \cdot 0 \\
40 \cdot 0 \\
39 \cdot 1 \\
44 \cdot 7 \\
49 \cdot 7 \\
5 \overline{55 \cdot 0} \\
38 \cdot 7\end{array}$ \\
\hline
\end{tabular}

$10+$ 
TABLE III

PHYSICAL WORKING CAPACITY BEFORE AND AFTER TREATMENT

\begin{tabular}{|c|c|c|c|c|c|}
\hline \multirow[b]{2}{*}{ Patient } & \multirow{2}{*}{$\begin{array}{l}\text { Before or } \\
\text { during } \\
\text { treatment }\end{array}$} & \multicolumn{3}{|c|}{ Treadmill exercise study } & \multirow[b]{2}{*}{ Clinical result of treatment } \\
\hline & & $\begin{array}{c}\text { Resting } \\
\text { heart } \\
\text { rate/min. }\end{array}$ & $\begin{array}{c}\text { Maximum } \\
\text { heart } \\
\text { rate/min. }\end{array}$ & $\mathrm{PWC}_{150}$ * & \\
\hline $\begin{array}{l}\text { B. H. } \\
\text { S. H. } \\
\text { J. W. C. } \\
\text { J. L. } \\
\text { B. T. }\end{array}$ & $\begin{array}{l}\text { Before } \\
\text { During } \\
\text { Before } \\
\text { During } \\
\text { Before } \\
\text { During } \\
\text { Before } \\
\text { During } \\
\text { Before } \\
\text { During }\end{array}$ & $\begin{array}{r}80 \\
64 \\
112 \\
75 \\
100 \\
84 \\
88 \text { AF } \\
62 \\
93 \\
64\end{array}$ & $\begin{array}{r}160 \\
130 \\
170 \\
134 \\
140 \\
135 \\
170 \\
92 \\
148 \\
128\end{array}$ & $\begin{array}{c}4.5 \\
7 \cdot 5 \\
3 \cdot 0 \\
5 \cdot 6 \\
\frac{5 \cdot 8}{5 \cdot 8} \\
1 \mathrm{kpm} .170 / \mathrm{min} . \\
1 \mathrm{kpm} .92 / \mathrm{min} \\
4 \cdot 2 \\
6.0\end{array}$ & $\begin{array}{l}\text { Initial improvement } \\
\text { Initial improvement } \\
\text { No dizziness, but still short of breath } \\
\text { Deterioration with œdema } \\
\text { Great improvement }\end{array}$ \\
\hline
\end{tabular}

The heart rate achieved with maximum effort was lower in all patients on treatment, with the most marked reduction in $\mathrm{J}$. $\mathrm{L}$. who was in atrial fibrillation.

By virtue of the slowing of the heart rate on exercise, the pulse rate-work ratio (PWC) was increased, while the patients were taking propranolol. At a heart rate of 150 a minute all were able to do a greater amount of work.

\section{Discussion}

It is now generally accepted that muscular subaortic stenosis is a primary disease of the myocardium, which usually has its major functional impact on the left ventricle. Pearse (1964) has demonstrated in the myocardium removed from the septal region at operation the proliferation of sympathetic nerve fibres (sympathosis), with consequent and demonstrable increase in noradrenaline (noradrenosis). Whether or not this is the primary abnormality in muscular subaortic stenosis is unknown. It appears logical to evaluate the effect of blocking the action of this excess noradrenaline in patients with muscular subaortic stenosis on a long-term basis. Cherian et al. (1966) confirmed that betaadrenergic blockade had little or no effect on the hæmodynamics of muscular subaortic stenosis at rest. However, they did show that blockade would decrease or abolish the increase in dynamic obstruction resulting from exercise or isoprenaline infusion. Beta-adrenergic blockade with propranolol caused a significant reduction in heart rate, both at rest and on exercise, in all our patients. It was hoped that long-term treatment, while reducing the frequency of syncopal attacks and dizzy turns associated with marked tachycardia, might also protect the patient from the possibility of sudden death due to arrhythmias. Optimistically it was also thought that the muscular hypertrophy associated with the condition might regress during long-term treatment with betaadrenergic blockade.

While initial symptomatic improvement was present in four of our five patients on long-term treatment, improvement was not dramatic in three of the four, and, in one, symptoms returned and then progressed and, finally, surgical treatment was advised. In only one patient was there dramatic improvement and this appeared to be associated with slowing of the heart rate during exercise.

In one patient, where propranolol was associated with clinical deterioration, this was probably due to the removal of the patient's sympathetic drive to the myocardium. This patient (J. L.) showed sensitivity to propranolol, as judged by the reduction in the resting and the exercise heart rate. "'Heart failure" was precipitated with increased fluid retention, despite the better control of heart rate both at rest and on exercise. It is recommended that when a patient exhibits classical evidence of heart failure associated with muscular subaortic stenosis, beta-adrenergic blockade should only be used with great caution, as the drug may remove the essential sympathetic drive and lead to death.

Cherian et al. (1966) reported subjective improvement in 10 of their 13 patients treated with betaadrenergic blockade. Using a similar dosage régime our results were less favourable. It is suggested that propranolol has a definite, but probably limited, place in the management of patients with symptoms associated with muscular subaortic stenosis. In the patient in whom the symptoms are specifically related to undue tachycardia on exertion, a good initial response may be anticipated. The heart rate work ratio is reduced, allowing longer time for diastolic filling, and perhaps this explains the relief from syncope on exertion and the reduction in incidence of ischæmic chest pain.

There is no evidence as yet that long-term treat- 
ment will cause regression in the ventricular hypertrophy; however, it is suggested that prolonged treatment with beta-adrenergic blockade will reduce the noradrenaline content of the myocardium. When fluid retention has occurred in muscular subaortic stenosis, beta-adrenergic blockade is probably contraindicated.

\section{SUMMARY}

This paper reports the results of long-term treatment with a beta-adrenergic blocking drug (propranolol) in five patients with proven muscular subaortic stenosis. Four patients showed initial improvement. However, treatment had to be discontinued in the fifth patient because of increased fluid retention and shortness of breath. There was no change in the ventilatory capacity after treatment, nor was there significant change in the ventilatory response to exercise. The physical working capacity (pulse rate/work ratio) showed an improvement in all five patients, due to the marked reduction of heart rate at rest and on exercise. It is suggested that the patients most likely to benefit from this form of treatment are those with symptoms associated with a high resting and exercise heart rate. Patients demonstrating fluid retention should not be treated with beta-adrenergic blockade. Although our experience is still small, it is suggested that beta-adrenergic blockade may be of value in the long-term management of certain patients with muscular subaortic stenosis; however, surgical treatment will be required in those patients who do not maintain initial improvement, or in those where blockade is contraindicated.

\section{REFERENCES}

Braunwald, E., Brockenbrough, E. C., and Frye, R. L. (1962). Studies on digitalis. V. Comparison of the effects of ouabain on left ventricular dynamics in valvular aortic stenosis and hypertrophic subaortic stenosis. Circulation, 26, 166.
- , and Ebert, P. A. (1962). Hemodynamic alterations in idiopathic hypertrophic subaortic stenosis induced by sympathomimetic drugs. Amer. F. Cardiol., 10, 489.

Brent, L. B., Aburano, A., Fisher, D. L., Moran, T. J., Myers, J. D., and Taylor, W. J. (1960). Familial muscular subaortic stenosis. Circulation, 21, 167.

Brock, R. C. (1957). Functional obstruction of the left ventricle. Guy's Hosp. Rep., 106, 221.

- (1959). Functional obstruction of the left ventricle. Guy's Hosp. Rep., 108, 126.

Brockenbrough, E. C., Braunwald, E., and Morrow, A. G. (1961). A hemodynamic technic for the detection of hypertrophic subaortic stenosis. Circulation, 23, 189.

Cherian, G., Brockington, I. F., Shah, P. M., Oakley, C. M., and Goodwin, J. F. (1966). Beta-adrenergic blockade in hypertrophic obstructive cardiomyopathy. Brit. med. $\mathcal{F}$., 1, 895.

Cohen, J., Effat, H., Goodwin, J. F., Oakley, C. M., and Steiner, R. E. (1964). Hypertrophic obstructive cardiomyopathy. Brit. Heart f., 26, 16.

Criley, J. M., Lewis, K. B., White, R. I., Jr., and Ross, R. S. (1965). Pressure gradients without obstruction: a new concept of "hypertrophic subaortic stenosis". Circulation, 32, 881 .

Goodwin, J. F., Hollman, A., Cleland, W. P., and Teare, D. (1960). Obstructive cardiomyopathy simulating aortic stenosis. Brit. Heart f., $22,403$.

Hellerstein, H. K., Hirsch, E. Z., Cumler, W., Allen, L., Polster, S., and Zucker, N. (1963). Reconditioning of the coronary patient. In Coronary Heart Disease (a Hahnemann Symposium), ed. W. Likoff, and J. J. Moyer, p. 448. Grune and Stratton, New York.

Morrow, A. G., and Braunwald, E. (1959). Functional aortic stenosis. Circulation, 20, 181.

Pearse, A. G. E. (1964). Ciba Foundation Symposium on Cardiomyopathies. J. and A. Churchill, London.

Pitt, A., Sloman, G., and Munro, J. A. (1964). The clinical application of a physical working capacity test. Med. f. Aust., 1, 472.

Sjostrand, T. (1960). Functional Capacity and Exercise Tolerance in Patients with Impaired Cardiovascular Function in Clinical Cardio-Pulmonary Physiology. Grune and Stratton, New York.

Sloman, G., and Gandevia, B. (1964). Ventilatory capacity and exercise ventilation in congenital and acquired cardiac disease. Brit. Heart f., 26, 121.

Teare, D. (1958). Asymmetrical hypertrophy of the heart in young adults. Brit. Heart $\mathcal{f}$., 20, 1.

Wigle, E. D., Heimbecker, R. O., and Gunton, R. W. (1962). Idiopathic ventricular septal hypertrophy causing muscular subaortic stenosis. Circulation, 26, 325. 